Якимчук А. Ю. ${ }^{[1 ;}$ ORCID ID: 0000-0002-5038-5215], д.е.н., професор, професор кафедри державного управління, документознавства та інформаційної діяльності

${ }^{1}$ Національний університет водного господарства та природокористування, м. Рівне

\title{
ОРГАНІЗАЦІЙНО-ЕКОНОМІЧНІ ЗАСАДИ РОЗВИТКУ РИНКУ ЕКОЛОГІЧНИХ ТОВАРІВ Й ПОСЛУГ У КОНТЕКСТІ ЄВРОАТЛАНТИЧНОЇ ІНТЕГРАЦІї УКРАЇНИ
}

Розвиток ринку екологічних товарів і послуг набув значного поширення у розвинених державах світу, де сформовано інструменти державного регулювання такого ринку, економічні інструменти стимулювання діяльності підприємств у впровадженні екологічних інновацій, застосування механізмів торгівлі квотами на викиди тощо. Україна, маючи євроінтеграційні прагнення, повинна сформувати та адаптувати власний ринок екологічних товарів і послуг згідно вимог Європейського Союзу, міжнародних директив і програм. У період екологічної нестабільності України, особливу роль у збереженні природних ресурсів, біорізноманіття, об'єктів природно-заповідного фонду (ПЗФ) в подальшому відіграватиме такий ринок. У даній статті розглянуто перспективи формування ринку екологічних товарів та послуг в Україні, формування організаційно-економічних засад його ефективного функціонування. Проаналізовано фактичний стан розвитку ринку екологічних товарів і послуг у країнах Європейського Союзу й окреслено нові тенденції формування національного ринку екологічних товарів і послуг відповідно до концепції сталого розвитку.

Ключові слова: ринок; держава; послуги; товари; природні ресурси; міжнародна співпраця; сталий розвиток.

Постановка проблеми. Україна має значні здобутки у своїх євроінтеграційних прагненнях. Згідно Угоди про асоціацію, хоча й намічено кінцевий термін виконання Україною всіх їі положень на 2025 рік, проте у частині секторальної інтеграції Україна має завершити виконання низки зобов'язань не пізніше кінця 2023 року. Це стосується й формування ринку екологічних товарів та послуг. Необхідно зазначити, що більшість положень Угоди має бути виконано до кінця каденції Президента В. Зеленського і нинішнього складу Єврокомісії. Саме тому варто оцінити, яким є стан виконання Угоди на початок 2021 року. Ще з 2019 року уряд провів переговори з ЄС щодо оновлення Додатку XXVII до УА (у сфері енергетики); виконав зобов'язання у сфері технічних бар'єрів у торгівлі, необхідне 
для укладення угоди ACAA; розпочав реформу митниці, 3 іï перетворенням на окремий орган державної влади; підготував плани гармонізації у сфері телекомунікацій й інших складових цифрового ринку і забезпечив ухвалення законодавства про електронні довірчі послуги; провів значні реформи у сфері державних закупівель [1]. Восени 2019 року, за кілька перших місяців роботи нового парламенту, було ухвалено низку важливих для виконання УА законопроєктів, які були розроблені, але так і не були (остаточно) ухвалені за попередньої каденції - зокрема, у сферах митних процедур, технічних бар'єрів у торгівлі, державних закупівель, регулюванні ринку фінансових послуг. Окрім того, відбулися значні інституційні зміни: крім Державної митної служби, у новому уряді вперше було створено й окреме Міністерство цифрової трансформації, що має значний вплив на реалізацію угоди із ЄС.

Україна, на початку 2019 року, отримала додаткові вимоги від ЄC для укладення Угоди про оцінку відповідності й прийняття промислової продукції (AСАА), які виконала наприкінці 2019 року. Європейський Союз погодив всеохопну стратегію імплементації Україною глави 4 розділу IV УА, яка стала змістом Додатку V до УА. Відповідно до нього, Україна взяла на себе зобов'язання виконати певні завдання у різних секторах сільськогосподарських товарів не пізніше 2021 року. На практиці українські виробники вже активно користуються можливістю індивідуальної сертифікації для експорту до ЄС. Все це сформувало мету, предмет та актуальність теми даного дослідження.

Аналіз останніх досліджень i публікацій. Питаннями формування ринку екологічних товарів та послуг займалися І. Синякевич, О. Врублевська, О. Веклич, М. Хвесик, В.Шевчук, К. Павлов, Ю. Стадницький та ін. Проте завданню організаційноекономічного забезпечення належного розвитку такого ринку достатньої уваги не приділялося. Все це зумовило предмет даного дослідження.

Постановка завдання. Дослідити перспективи розширення стимулятивних інструментів ефективного функціонування екологічного ринку товарів і послуг відповідно до концепції сталого розвитку, а також розроблення організаційно-економічних засад розвитку ринку екологічних товарів й послуг в умовах європейської інтеграції і практичних рекомендацій щодо вдосконалення механізму його регулювання в Україні.

Виклад основного матеріалу. Відомо, що формування й освоєння світового ринку екологічних товарів і послуг для України є 
можливістю для бізнесу. Наразі немає остаточної міжнародної класифікації цього ринку, чіткої статистики його розвитку, проте нині він існує і набирає обертів, особливо в розвинених країнах. Світовий ринок екологічних товарів і послуг, за оцінками експертів, $\epsilon$ фінансово насиченим (як мінімум, у розмірі 500 млрд дол.) й характеризується високою динамічністю й гнучкістю. Його щорічний приріст становить понад 5\%, в окремих країнах темпи приросту прогнозують ще вищими. Зокрема, у країнах Балтії приріст становить $8 \%$ щороку, у Канаді - 10\% у наступні п'ять років. Ринок екологічних товарів й послуг у країнах Східної Європи, включаючи СНД, оцінюють приблизно в 20 млрд дол. США, а його середньорічний приріст у понад 1\%. За прогнозами, вже у першій половині XXI століття, до 40\% світового виробництва становитиме продукція й технології, пов'язані з екологією й енергетикою [2]. Отож підприємства, що залучатимуть нові можливості використання екологічної складової бізнесу, отримають економічні переваги.

У зв'язку із тенденціями, які намітилися в Україні, актуальним питанням лишається ефективне регулювання ринку екологічних товарів і послуг. Під регулюванням ринку екологічних товарів та послуг розуміють, насамперед, комплексний механізм державного, інституціонального ринкового й міжнародного впливу на ринок екологічних товарів та послуг на основі системної взаємодії інструментів, заходів інституційного, організаційного, економічного, інформаційного й інноваційного забезпечення взаємодії суб'єктів на ринку із застосуванням системного, синергетичного, діалектичного та функціонального підходів.

Надзвичайно важливе значення у підвищенні ефективності сучасної екологічної політики, формуванні екологічної культури загалом має активізація природоохоронної діяльності, що стосується формування ринку екологічних товарів та послуг. Європейський Союз впродовж тривалого періоду регулює ринок товарів й послуг низкою нормативно-правових документів, основними з них є такі, як: Директива Комісії ЄС щодо органічного виробництва, маркування і контролю (№ 889/2008); Директива про екологічну відповідальність (2004/35/ЄC); Директива про стратегічну екологічну оцінку (2001/42/€C); Директива щодо оцінки впливу на навколишнє середовище (2014/52/ЄC); Директива Ради ЄС щодо органічного виробництва (№ 834/2007); Директива щодо охорони навколишнього природного середовища (2008/99/ЄС) [3; 5].

Індекс Євроінтеграційного Економічного Поступу $\epsilon$ інструментом для порівняльного оцінювання ступеня зближення регіональних економічних систем України, до складу якого належать 
індикатори глибини торговельно-економічних зв'язків регіону з $Є С$ й індикатори рівня інституційної підтримки, яку обласні державні адміністрації мають забезпечувати для підтримання євроінтеграційного поступу. Даний інструмент був розроблений Поліським фондом та застосований у співпраці 3 Асоціацією регіональних аналітичних центрів для всіх регіонів України [3].

Саме тому, в Україні актуальними $є$ питання щодо розроблення тих норм, що стосуються подальшої екологізації виробництва й забезпечення узгодженості законодавчих актів, які регулюють відносини в цій сфері. Серед першочергових заходів варто виділити такі:

- здійснити обґрунтування державної підтримки реалізації екологічних заходів, в т. ч. передбачених державними й галузевими програмами й планами;

- сприяти й стимулювати виробників до впровадження екологічно чистих виробництв;

- сформувати нормативно-законодавчу базу, яка би регулювала запровадження довгострокових стратегій й програм інтеграції екологічної політики до галузевих політик.

Першопричиною виникнення проблеми сталого розвитку $\epsilon$ глобальна екологічна криза, яка зумовлена зростанням руйнівного впливу на природне середовище і загрожує виживанню людини як біологічного виду. Її розв'язання можливе за умови переходу суспільства на шляху розвитку, що забезпечує потреби людей у межах можливостей біосфери. 3 цією метою Україна здійснює на своїй території екологічну політику, спрямовану на збереження безпечного для існування живої і неживої природи навколишнього середовища, захисту життя і здоров'я населення, досягнення гармонійної взаємодії суспільства і природи, охорону, раціональне використання і відтворення природних ресурсів.

У даній роботі проведено рейтингування областей України за показником інтегрального індексу з позицій розвитку екологічної продукції. Результати репрезентовано у табл. 1. Запропоновано ранжування регіонів України за трьома групами: група 1 - найвищий рівень за екологічним індексом (понад 11); група 2 - середній рівень за екологічним індексом (7-10); група 3 - найнижчий рівень за екологічним індексом (1-6).

Отже, як свідчать дані таблиці, отримані такі результати рейтингування: до першої групи із найвищим рівнем за екологічним індексом належать такі області, як Чернівецька, Дніпропетровська, Херсонська, Вінницька, Миколаївська. До другої групи із середнім рівнем за екологічного індексу посіла найбільш чисельна низка 
областей: Кіровоградська, Полтавська, Київська, Одеська, Житомирська, Закарпатська, Хмельницька, Рівненська, Запорізька, Чернігівська, Черкаська область.

Таблиця

Аналіз інтегральних індексів регіонів України щодо розвитку екологічної продукції

\begin{tabular}{|c|c|c|c|}
\hline \multirow{2}{*}{ Ранжування } & Область & $\begin{array}{c}\text { Значення } \\
\text { індексу без } \\
\text { врахування ваг }\end{array}$ & $\begin{array}{c}\text { Значення } \\
\text { індексу }\end{array}$ \\
врахування ваг
\end{tabular}

Джерело: узагальнено за [1-4; 9-10].

Третю групу зі найнижчим рівнем за екологічним індексом посіли такі регіони, як Сумська, Тернопільська, Харківська, Луганська, Львівська, Волинська, Івано-Франківська. Перше місце серед усіх регіонів України належить Чернівецькій області (210), останнє посіла Івано-Франківщина $(4,7)$.

Задля ефективного організаційно-економічного забезпечення функціонування ринку екологічних товарів та послуг, в Україні, 
насамперед, необхідно вирішити низку екологічних завдань, а саме [4]:

- поліпшення якості питної води;

- стабілізація й поліпшення екологічного стану в містах й промислових центрах Донецько-Придніпровського регіону;

- формування збалансованої системи природокористування на основі принципу гранично припустимих екологічних змін довкілля, ощадливого споживання природних ресурсів, зменшення й утилізація шкідливих викидів й відходів;

- збереження біологічної й ландшафтної різноманітності, розвиток природно-заповідної справи;

- застосування сучасних екологічно безпечних ресурсозберігаючих технологій;

- гарантування екологічної безпеки ядерних об'єктів й радіаційного захисту населення та довкілля;

- запобігання забрудненню Чорного й Азовського морів і поліпшення їхнього екологічного стану;

- будівництво нових й реконструкція діючих комунальних очисних каналізаційних споруд;

- екологізація промисловості, енергетики, будівництва, сільського господарства, транспорту;

- поліпшення екологічного стану річок України, зокрема басейну Дніпра;

- удосконалення системи моніторингу, розширення національної екологічної мережі [4].

Науковий і практичний інтерес становить дослідження місткості ринку органічної продукції в Україні. У даному дослідженні проведено аналіз місткості ринку органічної продукції в Україні впродовж 2006-2018 років, що наведено на рисунку.

Варто зазначити, серед причин, що гальмують розвиток екобезпечних інновацій в Україні, є такі як:

- відсутність мотиваційного механізму щодо запровадження екобезпечних інновацій суб'єктами підприємництва;

- недосконалість економічного механізму управління екобезпечними інноваціями;

- недосконалість законодавчої й інституційної бази розвитку екологічно орієнтованого інноваційного підприємництва;

- відсутність реальних джерел фінансування запровадження екобезпечних інновацій;

- нерозвиненість екологічної інфраструктури;

- недостатній розвиток екологічного підприємництва. 


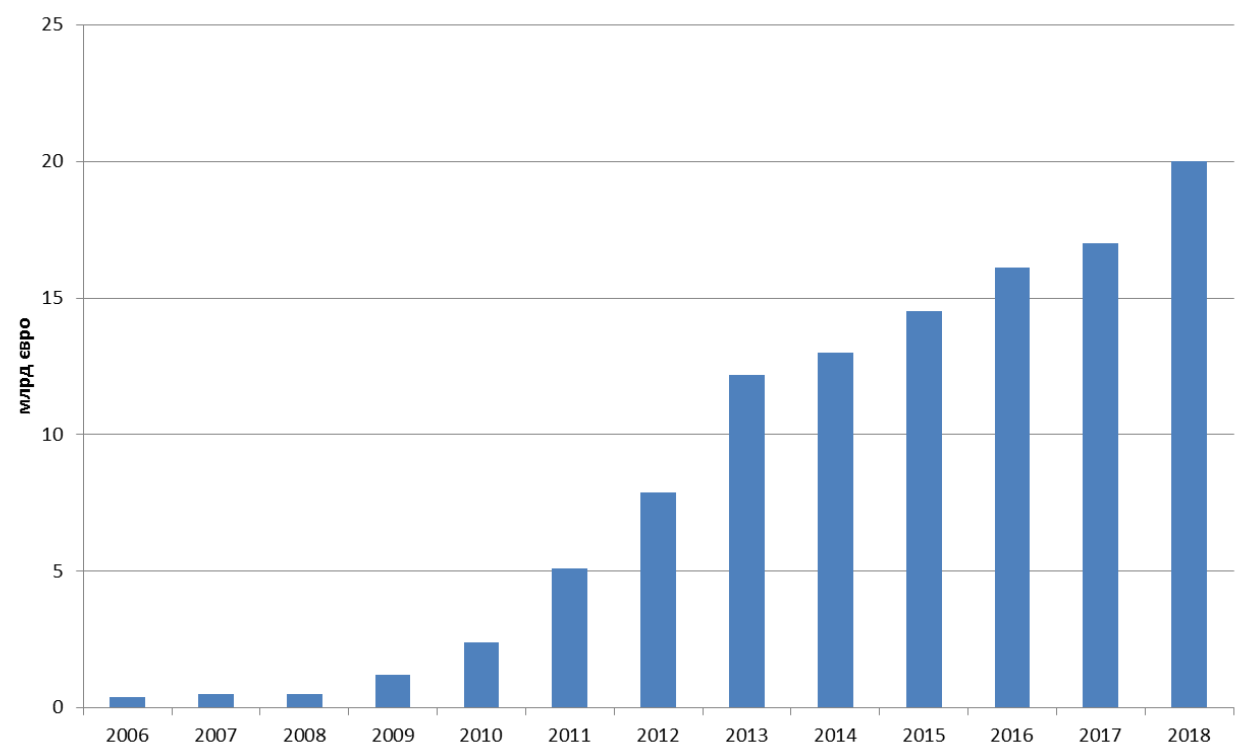

Рисунок. Місткість ринку органічної продукції України за 2006-2018 роки Джерело: сформовано за даними [1; 12].

Задля формування ефективного організаційно-економічного забезпечення функціонування ринку екологічних товарів і послуг у даній роботі запропоновано такі напрями удосконалення регулювання ринку екологічних товарів й послуг з урахуванням європейського досвіду:

- розвиток ринку органічного виробництва;

- розвиток циркулярної економіки;

- стимулювання розвитку еко-індустрії;

- інституційне забезпечення взаємоузгодження соціо-екологоекономічних інтересів стейкхолдерів;

- розширення джерел фінансування зеленого бізнесу;

- формування мотиваційного механізму впровадження екобезпечних інновацій.

Висновки. У світовій практиці дедалі більше утверджується розуміння того, що формування ринку екологічних товарів і послуг, $\epsilon$, насамперед, економічною інвестицією. Задля утворення тресту технологій охорони навколишнього середовища в США інвестори менше, ніж за два тижні зібрали 128 млн доларів, оцінивши це починання як надто вигідне. Заходи щодо охорони навколишнього середовища безпосередньо сприяють зниженню витрат виробництва, а також мінімізації втрат і переробленню відходів. Насправді, існує чимало позитивних прикладів закордонних підприємств, які отримують істотні прибутки «із сміття» чи «із повітря». Зараз триває підготовка Стратегії розвитку фінансового 
сектора України до 2025 року, ї̈ концепція передбачає запровадження основних норм законодавства ЄС, необхідних для отримання режиму внутрішнього ринку.

32019 року Україна і ЄC розпочали активний діалог про можливість укладення угоди про взаємне визнання електронних довірчих послуг. Нині також обговорюють можливість включення України, як першої країни - не члена ЄC, до Індексу цифрової економіки і суспільства (DESI), який вимірює прогрес країн-членів ЄC у різних вимірах Європейського цифрового ринку. У першій половині 2019 року було оновлено Додаток XXVII до УА, що оновив зміст українського «домашнього завдання» й запровадив механізм моніторингу його виконання. Українське законодавство вже значно наближене до «acquis» у сфері ринку природного газу. У першому півріччі 2019 року відбувся перехід зі щомісячного на добове балансування ринку, як у країнах ЄС, а в кінці 2020 року суттєве підвищення тарифів.

У даній роботі проведено рейтингування областей України за показником інтегрального індексу з позицій розвитку екологічної продукції, що дозволило розподілити регіони України за трьома нерівномірними групами: до першої групи із найвищим значенням екологічного індексу належать п'ять областей: Чернівецька Дніпропетровська, Херсонська, Вінницька, Миколаївська; до другої групи із середнім рівнем екологічного індексу належать одинадцять областей (Кіровоградська, Полтавська, Київська, Одеська, Житомирська, Закарпатська, Хмельницька, Рівненська, Запорізька, Чернігівська, Черкаська область); третю групу зі найнижчим значенням екологічного індексу здобули сім регіонів (Сумська, Тернопільська, Харківська, Луганська, Львівська, Волинська, ІваноФранківська області). Отже, формування ефективного організаційноекономічного забезпечення ринку екологічних товарів і послуг в Україні сформує умови до економічного зростання й втілення положень концепції сталого розвитку.

1. Євроінтеграція на стику влад: чи є успіхи України у впровадженні реформ. Громадська синергія. URL: http://www.civic-synergy.org.ua (дата звернення: 07.12.2020). 2. Федерація органічного руху України. URL: http:// organic.com.ua/uk/homepage (дата звернення: 08.12.2020). 3. Індекс ЄЕП - рух регіонів на шляху до Європейського економічного простору. URL: http:/pard.org.ua (дата звернення: 10.12.2020). 4. Індикатори й показники екорозвитку. Основні напрями й механізми забезпечення збалансованого розвитку України та їі регіонів : усі уроки до курсу «Екологія». URL: http://history.vn.ua (дата звернення: 06.12.2020). 5. Про охорону навколишнього природного середовища : Закон України від 25.06.91. Відомості Верховної Ради України. 1991. № 41 (08.10.91). 
Серія «Економічні науки»

Випуск 4(92) 2020 p.

Ст. 546. 6. Синякевич І. М. Інструменти екополітики: теорія і практика. Львів : ЗУКЦ, 2003. 188 с. 7. Стратегія державної екологічної політики України на період до 2020 року. Офіційний сайт Мінприроди України. URL: http://www. menr.gov.ua/ index.php/about/strategy (дата звернення: 14.12.2020). 8. Формування та реалізація національної екологічної політики України / О.О. Веклич, С.М. Волошин, Л. В. Жарова та ін. ; за наук. ред. С. О. Лизуна, ДУ «ІЕПСР НАНУ». Суми : Університетська книга, 2012. 336 с. 9. Onyshchuk S., Buryk Z., Knysh P. Management of the economic potential of territories in the context of sustainable development: case of Ukraine. Problems and perspectives in management. Business perspectives. 2019. Vol. 17, Issue 4. Рp. 13-25. 10. Якимчук А. Ю. Інтернаціоналізація діяльності сучасного університету: імплементація заходів підвищення якості освіти. Інноваційний університет і лідерство: проект і мікропроекти - III : зб. статей / відповідальні редактори Т. Фініков, Р. Сухарські. Варшава : Wydziat «Artes Liberales» UW, 2019. 412 c. C. 122-130. ISBN 978-83-63636-84-5. 11. Zoriana Buryk, Vitalii Bashtannyk, Faig Ragimov. Economic growth: macroeconomic effects of Public Borrowings at the global level. Problems and Perspectives in Management. 2019. Vol. 17, Issue 3. Рp. 169-183. 12. Тарасова Н. П., Кручина Е.Б. Индексы и индикаторы устойчивого развития. Устойчивое развитие: природа - общество человек : материалы международной конференции. М. : Министерство природных ресурсов, 2006. С. 127-144.

\section{REFERENCES:}

1. Yevrointehratsiia na styku vlad: chy ye uspikhy Ukrainy u vprovadzhenni reform. Hromadska synerhiia. URL: http://www.civic-synergy.org.ua (data zvernennia: 07.12.2020). 2. Federatsiia orhanichnoho rukhu Ukrainy. URL: http:// organic.com.ua/uk/homepage (data zvernennia: 08.12.2020). 3. Indeks YeEP - rukh rehioniv na shliakhu do Yevropeiskoho ekonomichnoho prostoru. URL: http:/pard.org.ua (data zvernennia: 10.12.2020). 4. Indykatory y pokaznyky ekorozvytku. Osnovni napriamy y mekhanizmy zabezpechennia zbalansovanoho rozvytku Ukrainy ta yii rehioniv : usi uroky do kursu «Ekolohiia». URL: http://history.vn.ua (data zvernennia: 06.12.2020). 5. Pro okhoronu navkolyshnoho pryrodnoho seredovyshcha : Zakon Ukrainy vid 25.06.91. Vidomosti Verkhovnoi Rady Ukrainy. 1991. № 41 (08.10.91). St. 546. 6. Syniakevych I. M. Instrumenty ekopolityky: teoriia i praktyka. Lviv : ZUKTs, 2003. 188 s. 7. Stratehiia derzhavnoi ekolohichnoi polityky Ukrainy na period do 2020 roku. Ofitsiinyi sait Minpryrody Ukrainy. URL: http://www. menr.gov.ua/ index.php/about/strategy (data zvernennia: 14.12.2020). 8. Formuvannia ta realizatsiia natsionalnoi ekolohichnoi polityky Ukrainy / O. O. Veklych, S. M. Voloshyn, L. V. Zharova ta in. ; za nauk. red. S. O. Lyzuna, DU «IEPSR NANU». Sumy : Universytetska knyha, 2012. 336 s. 9. Onyshchuk S., Buryk Z., Knysh P. Management of the economic potential of territories in the context of sustainable development: case of Ukraine. Problems and perspectives in management. Business perspectives. 2019. Vol. 17, Issue 4. Pp. 13-25. 10. Yakymchuk A. Yu. Internatsionalizatsiia diialnosti suchasnoho universytetu: implementatsiia zakhodiv pidvyshchennia yakosti osvity. Innovatsiinyi universytet i liderstvo: proekt i mikroproekty - III : zb. statei / vidpovidalni redaktory T. Finikov, R. Sukharski. Varshava : Wydział «Artes Liberales» UW, 2019. 412 c. C. 122-130. ISBN 978-83-63636-84-5. 11. Zoriana Buryk, Vitalii Bashtannyk, Faig Ragimov. Economic growth: macroeconomic effects of Public Borrowings at the global level. Problems and Perspectives in Management. 2019. Vol. 17, Issue 3. Pp. 169-183. 12. Tarasova N. P., Kruchina E. B. Indeksyi i indikatoryi 
ustoychivogo razvitiya. Ustoychivoe razvitie: priroda - obschestvo - chelovek : materialyi mejdunarodnoy konferentsii. M. : Ministerstvo prirodnyih resursov, 2006. S. 127-144.

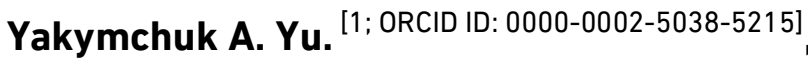
Doctor of Economics, Professor of Department of Public Administration, Documentation and Informational Activity

${ }^{1}$ National University of Water and Environmental Engineering, Rivne

\section{ORGANIZATIONAL AND ECONOMIC FUNDAMENTALS OF ENVIRONMENTAL GOODS AND SERVICES MARKET DEVELOPMENT IN THE CONTEXT OF UKRAINE'S EURO-ATLANTIC INTEGRATION}

The development of the market of ecological goods and services has become widespread in developed countries, where the instruments of state regulation of such a market, economic tools to stimulate enterprises in implementing environmental innovations, the use of mechanisms for emissions trading, etc. This paper ranks the regions of Ukraine according to the integrated index from the standpoint of environmental development, which allowed to divide the regions of Ukraine into three groups: the first group with the highest level of environmental index includes five regions, as Chernivtsi, Dnipropetrovsk, Kherson, Vinnytsia, Mykolayiv; the second group with an average level of ecological index includes eleven oblasts (Kirovohrad, Poltava, Kyiv, Odesa, Zhytomyr, Zakarpattia, Khmelnytskyi, Rivne, Zaporizhia, Chernihiv, Cherkasy oblasts); the third group with the lowest value of the ecological index was won by seven regions (Sumy, Ternopil, Kharkiv, Luhansk, Lviv, Volyn, Ivano-Frankivsk regions). Thus, the formation of effective organizational and economic support for the market of environmental goods and services in Ukraine will create the conditions for economic growth and implementation of the provisions of the concept of sustainable development. This article examines the prospects for the formation of the market of environmental goods and services in Ukraine, the formation of organizational and economic foundations of its effective functioning. The actual state of development of the market of ecological goods and services in the countries of the European Union has been analyzed and new tendencies of formation of the national market of ecological goods and services according to the concept of sustainable development have been outlined.

Keywords: market; state; services; goods; natural resources; international cooperation; sustainable development. 
Якимчук А. Ю. [1; ORCID ID: 0000-0002-5038-5215], д.э.н., профессор, профессор кафедры государственного управления, документоведения и информационной деятельности

${ }^{1}$ Национальный университет водного хозяйства и природопользования, г. Ровно

\section{ОРГАНИЗАЦИОННО-ЭКОНОМИЧЕСКИЕ ОСНОВЫ РАЗВИТИЯ РЫНКА ЭКОЛОГИЧЕСКИХ ТОВАРОВ И УСЛУГ В КОНТЕКСТЕ ЕВРОАТЛАНТИЧЕСКОЙ ИНТЕГРАЦИИ УКРАИНЫ}

Развитие рынка экологических товаров и услуг широко распространен в развитых странах мира, где сформированы инструменты государственного регулирования такого рынка, экономические инструменты стимулирования деятельности предприятий по внедрению экологических инноваций, применения механизмов торговли квотами на выбросы и тому подобное. В данной работе проведено рейтингования областей Украины по показателю интегрального индекса с позиций развития экологической продукции, что позволило распределить регионы Украины по трем следующим группам: в первую группу с высоким уровнем значения экологического индекса принадлежат пять областей: Черновицкая, Днепропетровская, Херсонская, Винницкая, Николаевская; ко второй группе со средним уровнем экологического индекса принадлежат одиннадцать областей (Кировоградская, Полтавская, Киевская, Одесская, Житомирская, Закарпатская, Хмельницкая, Ровенская, Запорожская, Черниговская, Черкасская область); третью группу с самым низким значением экологического индекса получили семь регионов (Сумская, Тернопольская, Харьковская, Луганская, Львовская, Волынская, Ивано-Франковская области). Следовательно, формирование эффективного организационноэкономического обеспечения рынка экологических товаров и услуг в Украине создаст условия для экономического роста и воплощения положений концепции устойчивого развития. В данной статье рассмотрены перспективы формирования рынка экологических товаров и услуг в Украине, формирование организационно-экономических основ его эффективного функционирования. Проанализированы фактическое состояние развития рынка экологических товаров и услуг в странах Европейского Союза и обозначены тенденции формирования национального рынка экологических товаров и услуг в соответствии с концепцией устойчивого развития.

Ключевые слова: рынок; государство; услуги; товары; природные ресурсы; международное сотрудничество; устойчивое развитие. 